\title{
8. Conclusion: the entangled paths towards European solidarity
}

\section{Christian Lahusen}

\subsection{INTRODUCTION}

Solidarity is a lived experience in Europe, if we consider attitudes and practices of European citizens (e.g., donations, volunteering or protest participation), civil society initiatives and campaigns (e.g., cooperatives, self-help groups, social enterprises or time banks), and social rights and public policies of redistribution by the modern welfare state. European solidarity, however, is a much more contested and fragile phenomenon. The principle of solidarity inspires the treaties of the European Union, but it is weakly entrenched in European legislation, and policy initiatives devoted to interstate solidarity are exposed to contestation and countermobilisation within the public sphere. Civil society organisations are committed to sustaining solidarity within their immediate environment and invest considerable energy in organising related activities, but they are limited in their ability to establish cross-national platforms and patterns of work. And public opinion polls show that European citizens engaged in solidarity practices towards fellow citizens also support the rights of other Europeans, but even these citizens tend to prioritise other targets, and thus are less engaged in supporting the causes of other Europeans.

In these broad terms we can summarise some of the main findings of the yearlong research work leading to this book. Findings emanate from an EU-funded project that was committed to a systematic analysis of transnational solidarity in times of crises. The mission of TransSOL was to take a careful look at the state of (European) solidarity, and thus to look beyond potential appearances. In fact, most people will much more likely subscribe to the idea of solidarity in its broader sense. Hence, it is necessary to dig into issue- and target-specific forms of solidarity in order to obtain a more nuanced and authentic picture. Our assumption was that citizens, organisations and policy-makers would prioritise specific groups or issues; they might even have clear ideas of who does and does not deserve support. With this backdrop in mind, we centred our analysis 
on various target groups, both in terms of vulnerable groups (people with disabilities, the unemployed, and immigrants and asylum seekers) and spatial entities (own country, Europe and the non-European world). Additionally, the research aimed at painting a comprehensive picture of practised solidarity by arguing that solidarity is constructed and organised at various levels of aggregation, namely the levels of citizens, civil societies and nation-states. Consequently, TransSOL was committed to mapping and analysing (European) solidarity dispositions and practices at each of these levels, with regard to practices of interpersonal support within and beyond borders; with a focus on organised forms of solidarity in terms of citizens' groups, initiatives and associations, and their webs of transnational solidarity work within and beyond borders; and finally, with regard to institutionalised forms of solidarity in terms of social rights and entitlements, and public discourses about solidarity within and beyond borders. The European coverage of our research (Denmark, France, Germany, Greece, Italy, Poland, Switzerland and the UK) allowed us to map solidarity in all these dimensions, and in very diverse national contexts. The multinational composition of the research team enabled us to engage in a comparative analysis of factors and forces promoting or inhibiting solidarity within Europe.

Our research was guided by a number of assumptions that build on the analytic framework presented and developed in Chapter 1 of this volume. With regard to the various levels of analysis, however, there was a need to be more specific with the factors impinging on European solidarity. In fact, what emerged recurrently from our analysis was an apparent contentiousness and fragility of European solidarity. Understanding levels, forms and prospects of European solidarity thus required an informed analysis of those forces and factors that further or limit it. Based on previous research, we developed a number of assumptions that guided our empirical analyses.

First, it was argued that individual solidarity would most probably be patterned along socio-demographic traits and constituencies. In particular, we assumed that the propensity to support others (including, in particular, other Europeans) would be more diffused among people with a higher social class status, stronger shares in bridging social capital, postmaterialist values, and political orientation towards the left. Second, our research built on the proposition that civil society organisations provide arenas and opportunities for the mobilisation and reproduction of solidarity, and that European solidarity is thus dependent on an organisational field with a related supply chain. On this analytical level, we assumed that European solidarity would most probably be limited by the uneven development of civil societies across the eight countries under analysis, and by the more local and national outlook of established organisational fields. 
Third, the research work followed the assumption that solidarity is not only dependent on an organisational supply, but also on the institutional and legal frameworks established by the nation-states and the European Union. In this regard, we argued that the institutionalisation of solidarity is marked by an unbalanced situation, according to which solidarity is overall weakly established at the EU level, while being much more forcefully institutionalised at the national level. This situation most probably discourages transnational forms of solidarity at the level of citizens and civil societies, because the latter is contained and constrained by a national frame of reference. However, it was expected that the specific timeframe would yield new challenges and opportunities for civic solidarity. In times of accelerating crises and emergency situations, the fact that citizens and civil society organisations become more active could not be excluded, particularly in countries with growing grievances and accelerating needs.

\subsection{THE FRAGILE AND CONTESTED NATURE OF (EUROPEAN) SOLIDARITY}

The findings presented in the previous chapters paint a nuanced picture of the state of solidarity within Europe. Some of the previously listed assumptions had to be refuted or reformulated. One the one hand, solidarity turned out to be a relevant issue across different population groups, organisational fields and policy domains. On the other hand, solidarity is affected by a number of conditioning factors that tend to vary across country and fields. Overall, however, the contested and fragile nature of solidarity is confirmed at each level of analysis: the micro, meso and macro.

In regard to the individual level, in late 2016 we conducted an online survey among a representative sample of residents. Although our own findings confirm results from previous research, we can highlight some interesting deviations (see Grasso and Lahusen, Chapter 2 in this volume). In the first instance, we note that Europeans largely approve of redistributive policies geared at reducing income inequality (Burgoon, 2014). In our own survey, almost three-quarters considered the reduction of big income inequality as an important public policy goal. Additionally, a strong majority endorse the attempts of the EU to help countries outside Europe in fighting poverty and promoting development. Interestingly enough, the share of people engaged in personal acts of solidarity is higher than some previous studies have shown. While comparative analyses have shown that only every fifth European citizen had donated time or money to non-profit organisations (Bauer et al., 2013), and every third had joined an unconventional protest such as signing petitions or boycotting products 
(Hafner-Fink, 2012), our own survey shows that almost every second respondent reports having engaged in solidarity activities for people in their country, including donating money or time and/or protesting and engaging in voluntary associations. This seems to be a consequence of the crisis, given that levels of support for fellow citizens are highest in Greece, while support for refugees and asylum seekers is strongest in Greece and Germany. Greece has been severely affected by the Great Recession and/or the so-called refugee crisis, Germany in regard to the latter.

It becomes evident that Europeans support solidarity as a private and public virtue. As our findings show, however, this picture has to be disaggregated, because people tend to prioritise between groups when solidarity is at stake. Our respondents are most engaged in the support of people in their own country, and least supportive of fellow Europeans; in addition, they report more practices of solidarity towards the disabled, and the least with refugees. For many, solidarity is restricted to specific groups or entities (Hunt and Bendford, 2004; Stets and McCaffree, 2014), which they consider more deserving (van Oorschot, 2000, 2006). Moreover, solidarity seems to be closely tied to the notion of citizenship (Miller, 2000; Keating, 2009; Supiot, 2015). In fact, our respondents prefer to grant access to social benefits only to fellow citizens, and to migrants only under the condition that they work and pay taxes, and thus contribute to the country's well-being. In both cases, solidarity is highly conditional, and tied to norms of reciprocity and trustworthiness (see also Wheeless, 1978; Thielemann, 2003; Lengfeld et al., 2015).

The identification of constituencies delivered interesting findings, partially disproving our initial assumptions. Further analyses published recently (Lahusen and Grasso, 2018) show that solidarity practices are rather evenly distributed within the population. In fact, socio-demographic traits and social structural resources do not really help to dissociate the active from the inactive citizens across countries, thus disproving the general role of gender (Neill and Gidengil, 2006), age (Beyerlein and Bergstrand, 2013; Grasso, 2013), education (Bauer et al., 2013; Grasso, 2013) or occupational and class status (Wilson, 2000). While these factors do play a role in individual countries, they are not relevant per se; solidarity seems to belong to the routine activities of very different groups of people. More important are attitudinal dispositions like interpersonal trust and religiosity. Political motivations play a role, but there is no consistent pattern, thus highlighting that solidarity is, for many, a more social than political act. Finally, a notable difference was found between active and inactive citizens: respondents engaged in support of one target are most probably committed to furthering the cause of other groups as well, while inactive people tend towards consistent inactivity. These findings highlight 
that European solidarity is not necessarily in competition with solidarity towards fellow citizens, but rather compatible with the latter. Still, citizens tend to prioritise national solidarity to the detriment of European solidarity. We might interpret this peculiarity as a consequence of the predominance of national conceptions of solidarity and an implicit notion of subsidiarity: Other European citizens might be needy, but respondents feel less responsible for them as they assume that other nation-states and citizens will provide help for them.

The organisational analyses reflect this finding. The two chapters on the organisational fields at the grassroots and the national/European levels show that most citizens' groups, associations and networks are active at the local and national levels. Among the sample of grassroots groups, only every tenth organisation reports being active within Europe - both at the supranational level of the EU and/or in other countries (see Kousis et al., Chapter 3 in this volume). Among national organisations, the share of groups being active at the EU level is higher - i.e., almost every second organisation indicated this (see Baglioni and Montgomery, Chapter 4 in this volume). But once we ask for activity types, funding and membership in consultative bodies, the numbers drop considerably. Hence, also in this regard, the main ambit of operation is the country of birth and/or the most immediate surroundings. In this regard, our initial research assumption is corroborated. Civil societies are still strongly contained by the nationstate (Anheier and Salamon, 1999; Baglioni and Giugni, 2014), given the prevalence of nationally defined public policies, funding schemes and established consultation procedures, and probably the urgency of countryspecific problems and needs to be addressed, as well. Additionally, there are also marked differences between countries in the degree of European activities: Countries with more established civil societies seem to provide a more beneficial background for the development of European solidarity activities than countries with a less developed sector - as the comparative analysis of TransSOL data revealed (Lahusen et al., 2018).

Findings of our organisational analysis, however, do not suggest that European solidarity activism is altogether absent. Indeed, we have noted that civil society organisations from a number of very different countries are active at the EU level for very specific aims (e.g., funding, consultation, mobilisation). More importantly, however, we have to redirect our view away from the arena of EU governance and take it back to the grassroots level. A closer look at the data suggests that European solidarity is a matter of a specific organisational pattern: the activism is decentralised and localised, and it follows soft forms of transnationalism via cooperation and diffusion. This finding complements results from previous studies on the Europeanisation of civil societies and social movements. On the 
one hand, scholarly writing has been interested in the different scales of activities - from the local to the European. Studies have testified to the emergence of a European field of civil society (Smismans, 2006; Kröger, 2008; Kohler-Koch and Quittkat, 2013; Kutay, 2014), because the EU attracts local and national civil society organisations by providing funding, access to legislative processes and consultations and thus an arena of influence-taking (Kousis, 1999; Císař and Vráblíková, 2013; Sanchez Salgado, 2017). However, it is well known that these 'European' associations and networks have had problems mobilising their members' support at the local level (Della Porta and Tarrow, 2005; Petrova and Tarrow, 2007; Tarrow, 2011, 191-3). This resistance is also to do with the fact that the EU-governance system exerts accommodative pressures on civil society actors, many of which they are unwilling to adopt, given a more contentious action repertoire and a stronger orientation towards the grassroots level (Rucht, 2001; Balme and Chabanet, 2008). Hence, civil society organisations interested in furthering solidarity might thus willingly opt against a vertical Europeanisation, and thus against a scale shift towards the EU (Tarrow and McAdam, 2005). In these cases, activists might opt for a horizontal Europeanisation: local and national organisations expand their area of activities into other European countries mainly by means of cooperation with civic groups and organisations from other European nation-states (Lahusen et al., 2018).

We can thus assume that the organisational field of European solidarity is marked more strongly by a horizontal and transnational orientation. Additionally, this orientation goes along with a decentralised structure of organisation and activism. Both aspects are well-known in a social movement analysis (Imig and Tarrow, 1999; Della Porta and Caiani, 2009) that describes and explains mobilisation waves across space and time. The study of transnational protest waves has placed particular emphasis on the processes of diffusion of protest activities at the grassroots level. The strength of social movements resides more often than not in their ability to promote the diffusion of ideas and practices from one country into another (Della Porta and Tarrow, 2005; Tarrow, 2005). Findings show that global and/ or EU-level associations and networks play an important role in the diffusion and coordination of transnational protest activities (Smith et al., 1994; Keck and Sikkink, 1999; Smith, 2002; Ruzza and Bozzini, 2008). Following a conceptual distinction by Tarrow (2012), who distinguished between thick and thin diffusion, we thus propose speaking about soft and strong forms of transnational solidarity activities. In regard to organised European solidarity, soft forms of diffusion prevail when compared to strong ones. That is, strong forms of transnational solidarity place more weight on an organisation and formalisation of solidarity campaigns and 
activities in terms of formalised European platforms, networks and/or campaigns; soft forms of diffusion rest more strongly on a decentral web of loosely coupled (local, national) initiatives and organisations, engaged in information exchange, cooperation and ad hoc campaigning (Tarrow, 2012; Mattoni and della Porta, 2014).

The strength of civic solidarity in Europe does not reside, against this backdrop, on the ability of citizens to set up formal organisations with professionalised staff, hierarchical decision-making procedures and mass constituencies. On the contrary, activists seem to privilege forms of soft transnational solidarity with a clearly decentralised structure, rooted in specific localities and tied to specific constituencies. The former model might be more visible from the outside, as it resides in big, formal and professional working groups. But the latter might be more effective in its ability to mobilise support and further solutions in an extended range of localities. Its strength - and its weakness - reside thus in its ability to mobilise local support and maintain cross-national networks of exchange and cooperation throughout Europe.

This observation leads us to the final level of our analysis. Research has also been committed to analysing the role of solidarity as a legal principle and as a component of public policies in each of our eight countries, and within the legal framework of the EU. Moreover, we were interested in public debates about solidarity within the mass media, in order to grasp how far the notion of solidarity has been constructed and/or eroded within the public sphere. It is here that policy-makers and stakeholders deliberate about the political consequences of social problems and upcoming crises, and it is here that they form the 'publicised' public opinion that might influence the choices of their citizens. In fact, this macro level is important to better understand the political context within which civil society organisations and citizens operate.

The relevance of this legal, institutional and political context is corroborated by the findings presented in our previous chapters in two respects (see Federico, Chapter 5 in this volume). In the first instance, our analyses have shown that the principle of solidarity is very unevenly institutionalised within the constitutional frameworks and public policies, when comparing both national and European levels. Our findings (see also Federico and Lahusen, 2018) highlight that solidarity is part of the nation-state's legal framework in all eight countries, when looking at constitutional text, court rulings and public policies in the three policy fields under analysis (disabilities, unemployment, migration and asylum). While the levels, forms and rationales of welfare provision and social security are very different between countries (Esping-Andersen, 1990, 1996; Castels, 2004), the analyses have shown that solidarity is a common constitutional principle 
everywhere (also Ross, 2010). The situation is quite different, however, once we move to the European level, because the principle of solidarity is much less prominent there. EU treaties refer to this value in general terms (Art. 3 of the TEU), and as a goal in the area of asylum and immigration (Art. 80) and economic and energy policy (Arts 122 and 194 of the TFEU), but it is lacking in other areas. Moreover, member states and EU institutions have had problems meeting the expectations of this principle. Even though they are called on to respect the principle of solidarity, their incapacity to agree on shared responsibilities for the growing number of refuges immigrating to Europe since 2015 has demonstrated that solidarity is a marginal factor in factual EU policy-making.

This imbalance in the institutionalisation of solidarity seems to impact on the uneven organisation of solidarity within civil societies. As we have seen above, citizen groups, non-profit organisations and welfare associations operate mainly within the nation-state, while being Europeanised only to a lesser degree. This reflects institutional and legal parameters: the EU might be engaged in attracting civil society organisations to the European level by means of funding schemes and consultation procedures, but the social competencies of the EU are too weak to restructure nationally segmented civil societies into pan-European platforms and activities. Additionally, we have seen that citizens are primarily engaged in acts of solidarity within their own country and locality, both in terms of personal practices of support, and as members of civil society organisations. This national and local outlook makes sense, given that solidarity is strongly institutionalised within the nation-state. Nation-states establish social rights and entitlement, they administer funds for service delivery and they provide forums of political contestation and legal litigation. Hence, citizens' groups will most probably direct their appeals to their local, regional or national governments and public authorities. At the same time, citizens seem to be less encouraged to get active on a personal level in support of other Europeans, possibly because the national model of solidarity is deeply enshrined in individual citizens: Citizens seem to expect that everybody is taken care of by their own government, national civil society organisations and fellow citizens.

These observations, however, are not fully correct, because our findings show that citizens are active in support of other Europeans, both in individual terms and as part of civic groups and organisations. In structural terms, we might expect that the predominance of national solidarity discourages citizens and civil society organisations from engaging in transnational, European solidarity. However, in times of crises, this imbalance seems to generate contrary effects: The solidarity gap within the constitutional framework of the EU, its public policies and interstate 
bargains seem to call citizens and civil society organisations into action, when severe social grievances across national borders emerge. Citizens and civil society organisations tend to compensate for the deficiencies of public policies, both at the national and European level. This observation is not restricted to current times, because citizens and civil society groups have long been committed to combatting social problems and grievances, in part aggravated by ongoing processes of welfare retrenchment and policies of austerity (Pierson, 1994, 1996; Bonoli et al., 2000; della Porta, 2015). But this observation seems to apply in particular to our own times. In fact, our findings show that citizens and civil society organisations have been active since the start of the Great Recession which began in 2008, as well as during the so-called refugee crisis (2015) - another event which spawned a definitive reaction to the inability of member states to find solutions within their own territory, and the shared incapacity of national governments to agree on joint European solutions.

In this sense, European citizenry has been Europe's fire brigade in times when governments have had trouble coming to terms with rampant area fires. We find empirical evidence for this emergency relief in the mushrooming numbers of newly founded citizen groups in the area of unemployment during the periods of mass unemployment during the 1990s, and the subsequent Great Recession since 2008, but also in the strong increase in civil society initiatives responding to the heavy influx of refugees since 2015.

Moreover, the momentum of civic solidarity was palpable in public debates devoted to the refugee crisis in 2015, as our analysis of mass mediated news coverage shows strong initial support for the German 'welcoming culture' (see Cinalli et al., Chapter 6 in this volume). In the beginning, claims and activities of civil society had a great deal of influence on public debates within the media. Claims frequently addressed the causes of forced migration and commented on citizens' activities and volunteering. These voices were overwhelmingly positive, stressing the importance of solidarity. However, this moment of solidarity and unity within the public arena was not long lived - in reaction to violent incidents (e.g., the terror attacks in Paris, the sexual assaults on New Year's Eve in Cologne) political contestation against migration started to conquer the public arena, thus discontinuing this important momentum. Debates were spearheaded by political actors and centred on issues of migration management (e.g., border management, registration of asylum seekers, relocation of refugees, or cooperation with non-EU countries such as Turkey over retaining refugees in their country) and the problems of long-term integration of refugees, a more negative tone evident with regard to refugees and notions of solidarity towards them. 
The analysis of Facebook comment sections of mainstream newspapers highlights that bottom-up debates among media users do not diverge strongly from the picture painted by the analysis of reported claims in newspaper articles (see Trenz et al., Chapter 7 in this volume). Little affected by hate speech, user comments provide opportunities to contest news coverage and voice personal opinions. Findings show that commentators are generally more critical of refugees and immigration policies, when compared with the claims of policy-actors and stakeholders reported by the press articles. However, data reveal that solidarity is a highly contentious topic also within this arena. Commentators supporting refugees and immigration policies justify their opinion with reference to universal and unconditional solidarity, while opposing commentators centre on the priority of national solidarity and conditional help for non-nationals. We thus see that citizens are engaged in defining the meaning of solidarity, and that their participation in these online platforms is geared to impact on the collective understanding of this core value. The analysis of comments thus highlights that citizens themselves are well aware that public discourses are symbolic contentions about the interpretation and definition of values, and that the outcome of public debates might thus impact on the behaviour of collective and individual actors.

\subsection{AN UNCERTAIN FUTURE?}

The future of European solidarity seems thus to be uncertain. Findings of the TransSOL project presented in this book show that solidarity is deeply enshrined in the legal frameworks of Europe, in the values cherished by its citizens, and in the activities of civil society organisations. Hence, European solidarity seems to be sufficiently developed to endure and overcome moments of crisis (see also Gerhards et al., 2019). And even if Europe does not seem to be the primary target and reference point for solidarity among citizens and civic associations, this must not necessarily be a crucial point of concern. Solidarity might rank less highly in the prioritisation of European citizens, but there are indications to assume that there is not inevitably antagonism between national, European and global solidarities. The main division is between those engaged in solidarity and those who are inactive. This division seems to mirror political and cultural orientations, given that supporters of right-wing populist parties are less engaged in solidarity practices even towards nationals (Kiess and Trenz, 2019), while proponents of an open and inclusive conception of European citizenship are more active (Kurowska et al., 2019; Lahusen and Theiss, 2019). European solidarity might thus benefit from any type 
of solidarity activity, as it involves citizens in activities that confront the grievances of others.

The complementarity of solidarity is also a lesson to be drawn from the analysis of civil societies and social movements. Citizens' initiatives and civil society organisations seem to be committed mainly to local constituencies and tasks, but our findings suggest that the organisational field adapts quite quickly to upcoming crises and grievances and spurs considerable transnational activity through horizontal forms of diffusion and cooperation at the grassroots level (della Porta, 2009, 2015; Lahusen et al., 2018). Taking these insights seriously acknowledges that the best way of promoting organised European solidarity might not reside in the development of hierarchical, formalised and supranational platforms and associations, but rather in decentralised forms of cooperation, diffusion and engagement at the grassroots level.

What is rather an issue of concern is the regressive tendencies in the social, political and legal environment of civic solidarity. Citizens and civil society organisations have been responding to the dramatic emergency situations after the Great Recession since 2008 and the so-called refugee crisis of 2015. But the momentum of public solidarity lacked longevity in both cases, because European solidarity cannot reside in the voluntary and spontaneous engagement of European citizens. It requires institutional responses and public policies. The analysis shows, however, that policy responses are rather dominated by stagnation and regression, both in general terms and in view of the three issue fields under analysis. Schemes of unemployment and disability protection have been weakened with reference to fiscal and market imperatives, and solidarity with migrants and refugees has been limited due to security concerns - even in cases where solidarity is strongly entrenched in law. The crises might have aroused considerable solidarity from European citizens in terms of short-term relief, but they have reduced the strength of solidarity as a legal and political principle in the long term.

Given these contextual developments, it is very probable that European solidarity will remain highly contentious, dynamic and fragile. This is regrettable. Citizens do not seem to be against European solidarity per se. On the contrary, they tend to cherish the idea of solidarity, and this support does not exclude - in most cases, it actively includes - a European element. Disagreement emerges in the manner of organising and institutionalising solidarity in terms of rights, entitlements and benefits within Europe. Political institutions thus have to do their homework. A similar indication is applicable to the level of civic solidarity. As we have seen, there is a considerable number of Europeans who are ready to commit personally to solidarity with the needy, both within their country and 
beyond. But disengagement is very probable when political institutions are unable to find solutions, and counter-mobilisations seize the moment within the public sphere. Fragility also prevails at the organisational level of civil society. Groups and organisations are committed to furthering their specific goals in their circumscribed environment, but European networks and circuits of mutual support are more difficult to sustain in times of welfare retrenchment and national antagonism. Organisations committed to furthering European solidarity require moral, political and legal support. If European solidarity is such a highly valued force, it is imperative that more care be given to nurturing it.

\section{REFERENCES}

Anheier, H. K. and Salamon, L. M. (1999). Volunteering in cross-national perspective: initial comparisons. Law and Contemporary Problems, 62(4): 43-66.

Baglioni, S. and Giugni, M. (eds) (2014). Civil Society Organizations, Unemployment, and Precarity in Europe: Between Service and Policy. Basingstoke: Palgrave Macmillan.

Balme, R. and Chabanet, D. (2008). European Governance and Democracy. Power and Protest in the EU. Lanham, MD: Rowman \& Littlefield.

Bauer, T. K., Bredtmann, J. and Schmidt, C. M. (2013). Time vs. money: the supply of voluntary labor and charitable donations across Europe. European Journal of Political Economy, 32: 80-94.

Beyerlein, K. and Bergstrand, K. (2013). Biographical availability. In D. A. Snow, D. della Porta, B. Klandermans and D. McAdam (eds), The Wiley-Blackwell Encyclopedia of Social and Political Movements. New York: Wiley-Blackwell, pp. 137-8.

Bonoli, G., George, V. and Taylor-Gooby, P. (2000). European Welfare Futures. Oxford: Polity Press.

Burgoon, B. (2014). Immigration, integration, and support for redistribution in Europe. World Politics, 66(3): 365-405.

Castels, F. G. (2004). The Future of the Welfare State: Crisis Myths and Crisis Realities. Oxford: Oxford University Press.

Císař, O. and Vráblíková, K. (2013). Transnational activism of social movement organizations: the effect of European Union funding on local groups in the Czech Republic. European Union Politics, 14(1): 140-60.

della Porta, D. (2015). Social Movements in Times of Austerity: Bringing Capitalism Back into Protest Analysis. Cambridge: Polity Press.

della Porta, D. and Caiani, M. (2009). Social Movements and Europeanization. Oxford: Oxford University Press.

della Porta, D. and Tarrow, S. G. (eds) (2005). Transnational Protest and Global Activism. Lanham, MD: Rowman \& Littlefield.

Esping-Andersen, G. (1990). The Three Worlds of Welfare Capitalism. Cambridge: Polity Press.

Esping-Andersen, G. (1996). States in Transition: Social Security in the New Global Economy. London: Sage. 
Federico, V. and Lahusen, C. (2018). Solidarity as a Public Virtue? Law and Public Policies in the European Union. Baden-Baden: Nomos.

Gerhards, J., Lengfeld, H., Ignácz, Z., Kley, F. K. and Priem, M. (2019). European Solidarity in Times of Crisis: Insights from a Thirteen-Country Survey. London: Routledge.

Grasso, M. T. (2013). The differential impact of education on young people's political activism: comparing Italy and the United Kingdom. Comparative Sociology, 12(1): 1-30.

Hafner-Fink, M. (2012). Political participation, democratisation and citizens' values in Europe. Teorija in Praksa, 49(3): 544-65.

Hunt, S. A. and Benford, R. D. (2004). Collective identity, solidarity, and commitment. In D. A. Snow, S. A. Soule and H. P. Kriesi (eds), The Blackwell Companion to Social Movements. Oxford: Blackwell, pp.433-57.

Imig, D. and Tarrow, S. (1999). The Europeanization of movements? A new approach to transnational contention. In D. della Porta, H. P. Kriesi and D. Rucht (eds), Social Movements in a Globalizing World. Basingstoke: Palgrave Macmillan, pp. 112-33.

Keating, M. (2009). Social citizenship, solidarity and welfare in regionalized and plurinational states. Citizenship Studies, 13(5): 501-13.

Keck, M. E. and Sikkink, K. (1999). Transnational advocacy networks in international and regional politics. International Social Science Journal, 51(159): 89-101.

Kiess, J. and Trenz, H. J. (2019). Ties of solidarity and the political spectrum: partisan cleavages in reported solidarity activity across Europe. American Behavioral Scientist, 63(4): 459-74.

Kohler-Koch, B. and Quittkat, C. (2013). De-Mystification of Participatory Democracy: EU-Governance and Civil Society. Oxford: Oxford University Press.

Kousis, M. (1999). Sustaining local environmental mobilisations: groups, actions and claims in southern Europe. Environmental Politics, 8(1): 172-98.

Kröger, S. (2008). Nothing but consultation: the place of organised civil society in EU policy-making across policies. European Governance Papers, Nr. C-08-03.

Kurowska, A., Eisele. O. and Kiess, J. (2019). Welfare attitudes and expressions of (trans)national solidarity. American Behavioral Scientist, 63(4): 492-505.

Kutay, A. (2014). Governance and European Civil Society: Governmentality, Discourse and NGOs. London: Routledge.

Lahusen, C. and Grasso, M. (2018). Solidarity in Europe: Citizens' Responses in Times of Crisis. Cham: Palgrave Macmillan.

Lahusen, C., Kousis, M., Zschache, U. and Loukakis, A. (2018). European solidarity in times of crisis: comparing. transnational activism of civic organisations in Germany and Greece. Österreichische Zeitschrift für Soziologie, Supplement 1/43: 173-97.

Lahusen, C. and Theiss, M. (2019). European transnational solidarity: citizenship in action? American Behavioral Scientist, 63(4): 444-58.

Lengfeld, H., Schmidt, S. and Häuberer, J. (2015). Is There a European Solidarity? Attitudes towards Fiscal Assistance for Debt-Ridden European Union Member States. University of Leipzig: Report No. 67 (1 April).

Mattoni, A. and della Porta, D. (2014). Adapting theories on diffusion and transnational contention through social movements of the crisis: some concluding remarks. In D. della Porta and A. Mattoni (eds), Spreading Protests: Social Movements in Times of Crisis. Colchester: ECPR Press, pp. 277-89. 
Miller, D. (2000). Citizenship and National Identity. Cambridge: Polity Press.

Neill, B. and Gidengil, E. (eds) (2006). Gender and Social Capital. New York: Routledge.

Petrova, T. and Tarrow, S. (2007). Transactional and participatory activism in the emerging european polity: the puzzle of east central Europe. Comparative Political Studies, 40(1): 74-94.

Pierson, P. (1994). Dismantling the Welfare State? Reagan, Thatcher and the Politics of Retrenchment. Cambridge: Cambridge University Press.

Pierson, P. (1996). The new politics of the welfare state. World Politics, 48(2): 143-79.

Ross, M. G. (2010). A new constitutional paradigm for the EU? In M. G. Ross and Y. Borgmann-Prebil (eds), Promoting Solidarity in the European Union. Oxford: Oxford University Press, pp. 23-45.

Rucht, D. (2001). Lobbying or protest? Strategies to influence EU environmental policies. In D. Imig and S. Tarrow (eds), Contentious Europeans: Protest and Politics in an Emerging Polity. Lanham, MD: Rowman \& Littlefield, pp. 125-61.

Ruzza, C. and Bozzini, E. (2008). Organised civil society and European governance: routes of contestation. European Political Science, 7(3): 296-303.

Sanchez Salgado, R. (2017). Europeanization of civil society organizations in times of crisis? Exploring the evolution grant-seeking strategies in the EU multi-level system. European Politics and Society, 18(4): 511-28.

Smismans, S. (ed.) (2006). Civil Society and Legitimate European Governance. Cheltenham, UK and Northampton, MA, USA: Edward Elgar Publishing.

Smith, J. (2002). Bridging global divides? Strategic framing and solidarity in transnational social movement organizations. International Sociology, 17(4): 505-28.

Smith, J., Pagnucco, R. and Romeril, W. (1994). Transnational social movement organisations in the global political arena. Voluntas: International Journal of Voluntary and Nonprofit Organizations, 5(2): 121-54.

Stets, J. E. and McCaffree, K. (2014). Linking morality, altruism, and social solidarity using identity theory. In V. Jeffries (ed.), The Palgrave Handbook of Altruism, Morality, and Social Solidarity. New York: Palgrave Macmillan, pp. 333-51.

Supiot, A. (2015). La solidarité: enquête sur un principe juridique. Paris: Odile Jacob.

Tarrow, S. (2005). The New Transnational Activism. Cambridge: Cambridge University Press.

Tarrow, S. (2011). Power in Movement: Social Movements and Contentious Politics. Cambridge: Cambridge University Press.

Tarrow, S. (2012). Occupying America: Lessons for Social Movement Theory. Inaugural lecture at the Centre on Social Movement Studies. Florence: European University Institute.

Tarrow, S. and McAdam, D. (2005). Scale shift in transnational contention. In D. della Porta and S. Tarrow (eds), Transnational Protest and Global Activism. Lanham, MD: Rowman \& Littlefield, pp. 121-50.

Thielemann, E. R. (2003). Between interests and norms: explaining burden-sharing in the European Union. Journal of Refugee Studies, 16(3): 253-73.

van Oorschot, W. (2000). Who should get what, and why? On deservingness criteria and the conditionality of solidarity among the public. Policy \& Politics, 28(1): 33-48.

van Oorschot, W. (2006). Making the difference in social Europe: deservingness 
perceptions among citizens of European welfare states. Journal of European Social Policy, 16(1): 23-42.

Wheeless, L. R. (1978). A follow-up study of the relationship among trust, disclosure, and interpersonal solidarity. Human Communication Research, 4(2): 143-57.

Wilson, J. (2000). Volunteering. Annual Review of Sociology, 26: 215-40. 
Christian Lahusen - 9781789909500 Downloaded from PubFactory at 04/26/2023 10:22: 08AM via free access 